\title{
Membuat Konten Kampanye Lingkungan Bersih Pada Masa Pandemi Covid-19 di Kalangan Siswa SMAN 28 Jakarta
}

\author{
Wininda Qusnul Khotimah ${ }^{1}$, Sri Mustika ${ }^{2}$ \\ 1,2 Universitas Muhammadiyah Prof. Dr. Hamka, Jakarta - Indonesia
}

\begin{abstract}
ABSTRAK
Pandemi covid 19 yang berlangsung hampir dua tahun. Memberikan dampak yang cukup berimplikasi bagi setiap sendi kehidupan. Tidak terkecuali bagi keberlangsungan lingkungan hidup. Selama pandemi covid19, persoalan sampah medis menjadi persoalan baru. Permasalahan ini mulai dimunculkan oleh media massa arus utama juga media-media sosial. Persoalan sampah masker medis ternyata menjadi persoalan baru bagi hewan dan satwa di darat maupun laut. Beberapa hashtag sebagai bentuk edukasi mulai dimunculkan melalui media sosial, seperti \#potongtalielastismasker dan sejenisnya. Edukasi lingkungan hidup bisa dimulai dalam proses belajar mengajar di tingkat sekolah. Terbukti beberapa sekolah sekarng menerapkan sistem sekolah alam, atau melakukan field trip sebagai metode untuk meningkatkan kepedulian siswa terhadap lingkungan hidup. Sehingga, perlu adanya edukasi di kalangan remaja terkait persoalan lingkungan hidup yang terjadi di masa pandemic Covid-19. Edukasi tersebut dilakukan dengan cara penyuluhan dan pelatihan membuat konten untuk akun Instagram para siswa SMAN 28 Jakarta. Konten tersebut memuat edukasi tentang persoalan lingkungan hidup. Kegiatan ini juga berfungsi sebagai penerapan komunikasi lingkungan yang bertujuan sebagai tindakan advokasi terhadap lingkungan. Hasilnya, para pelajar tersebut lebih mengerti tentang persoalan lingkungan hidup dan mampu membuat konten yang berisi kampanye tentang lingkungan hidup.
\end{abstract}

Kata kunci: Komunikasi, Lingkungan, Kampanye, Covid-19, Instagram

\begin{abstract}
The COVID-19 pandemic has lasted almost two years. Gives a considerable impact on every aspect of life. No exception for environmental sustainability. During the COVID-19 pandemic, the issue of medical waste has become a new problem. This problem began to be raised by the mainstream mass media as well as social media. The issue of medical mask waste has turned out to be a new problem for animals and animals on land and at sea. Several hashtags as a form of education began to appear through social media. Environmental education can be started in the teaching and learning process at the school level. It is evident that several schools are now implementing the natural school system, or conducting field trips as a method to increase students' awareness of the environment. Thus, there is a need for education among teenagers regarding environmental issues that occurred during the Covid19 pandemic. The education was carried out through counseling and training to create content for the Instagram accounts of the students of SMAN 28 Jakarta. The content contains education about environmental issues. This activity also functions as the application of environmental communication which aims as an advocacy action towards the environment. As a result, these students understand
\end{abstract}


more about environmental issues and are able to create content containing campaigns about the environment.

Keywords: Communication, Environment, Campaign, Covid-19, Instagram

\section{PENDAHULUAN}

Pandemi covid 19 yang berlangsung hampir dua tahun. Memberikan dampak yang cukup berimplikasi bagi setiap sendi kehidupan. Tidak terkecuali bagi keberlangsungan lingkungan hidup. Selama pandemi covid19, persoalan sampah medis menjadi persoalan baru. Hal tersebut seperti yang dituliskan oleh kantor berita antara yakni, Indonesia menghadapi persoalan limbah medis yang membutuhkan penanganan khusus. Terhitung hingga Juli 2021 sebanyak 18.460 ton limbah medis B3 yaitu bahan berbahaya dan beracun (Violetta, 2021; Simanjuntak, 2021). Sampah medis ini meliputi alat pelindung diri (APD), baju hazmat, faceshield, dan masker medis bekas pakai.

Permasalahan yang cukup menjadi perbincangan ialah mengenai penggunaan masker medis sekali pakai. Studi terbaru memperkirakan, manusia sekarang menggunakan 129 miliar masker wajah setiap bulan di seluruh dunia. Jika satu bulan terdapat 31 hari, maka penggunaan ratarata masker sekali pakai sekitar 2,8 juta masker per menit, menurut penelitian yang dipublikasikan di jurnal Frontiers of Environmental Science and Engineering. Para peneliti memperingatkan besar volume limbah masker dengan komposisi plastiknya, yang dapat menimbulkan ancaman lingkungan (Saptoyo, 2021). Persoalan limbah masker adalah dampak lingkungan yang nyata dari munculnya pandemi ini. Jika sampah pastik sebanyak 25 persennya memiliki panduan dan cara untuk didaur ulang, maka berbeda dengan masker medis ini.

Masker medis sekali pakai menjadi persoalan sampah rumah tangga. Selama hampir dua tahun berlangsungnya pandemi covid 19, masyarakat mulai disadarkan adanya persoalan ini. Beberapa kampanye mulai dimunculkan terkait penggunaan masker medis sekali pakai. Permasalahan ini mulai dimunculkan oleh media massa arus utama juga media-media sosial. Meskipun, pada kenyataan persoalan lingkungan hidup masih belum menjadi perhatian di media arus utama di Indonesia (Khotimah, 2017). Tindak lanjut dari informasi ini seriingnya dilakukan atau dibagikan melalui Instagram dari penggiat-penggiat lingkungan. Misal saja, persoalan sampah masker medis ternyata menjadi persoalan baru bagi hewan dan satwa di darat maupun laut. Beberapa hashtag sebagai bentuk edukasi mulai dimunculkan melalui media sosial, seperti \#potongtalielastismasker \#potongtalimaskersblmdibuang \#potongtalimasker \#limbahmasker \#saveanimal. Penggunaan tagar tersebut sebagai bentuk kampanye kepedulian terhadap lingkungan yang disebabkan oleh sampah masker medis.

Persoalan lingkungan hidup bukanlah persoalan yang sederhana. Kerusakan lingkungan akan menetukan keberlangsungan hidup manusia. Keberadaan sampah oleh sebagian besar orang 
masih dipandang sebagai barang sisa yang harus dibuang dan tidak mempunyai nilai manfaat. Rendahnya tingkat kesadaran dan budaya masyarakat dalam pengelolaan sampah, penegakan regulasi tentang persampahan oleh pemerintah yang dirasa belum optimal, terbatasnya lahan untuk tempat pembuangan akhir serta paradigma masyarakat dalam memandang sampah sebagai barang sisa yang "tidak ada urusannya dengan saya" atau anggapan bahwa "alam dapat menyelesaikan dengan sendirinya" menjadi akar permasalahan belum terkelolanya sampah dengan baik.

Volume sampah akan terus meningkat seiring meningkatnya jumlah penduduk. Jumlah sampah di perkotaan diperkirakan meningkat lima kali lipat pada tahun 2020, yaitu menjadi 2,1 $\mathrm{kg}$ per orang/hari dari sebelumnya pada tahun 2000 , dan $0,8 \mathrm{~kg}$ perorang / hari di tahun tahun 2000 (Sucipto, 2012:11). Persoalan lingkungan hidup menjadi kajian tersendiri dalam IImu komunikasi. Akar utama kajian ini adalah komunikasi lingkungan. Komunikasi lingkungan sendiri adalah rencana dan strategi melalui proses komunikasi dan produk media untuk mendukung efektivitas pembuatan kebijakan, partisipasi publik, dan implementasinya pada lingkungan (Oepen, 1999:6).

Selanjutnya, Robert Cox dalam bukunya Environmental Communication and the Public Sphere, mengemukakan bahwa komunikasi lingkungan adalah sarana pragmatis dan konstitutif untuk memberikan pemahaman mengenai lingkungan kepada masyarakat, seperti halnya hubungan kita dengan alam semesta. Dengan kata lain komunikasi lingkungan digunakan untuk menciptakan kesepahaman mengenai permasalahan lingkungan (Cox, 2010:20).

Memberikan pemahaman mengenai lingkungan hidup kepada masyarakat memerlukan pengetahuan yang cukup tentang lingkungan hidup. Pemahaman memalui media massa ataupun media sosial mengenai persoalan lingkungan hidup umumnya dilakukan oleh seorang jurnalis lingkungan. Hal tersebut merupakan bagian dari fungsi jurnalisme lingkungan hidup yang memiliki tujuan untuk memberikan pencerahan, informasi sekaligus edukasi mengenai kesadaran pentingnya lingkungan, persoalan lingkungan hingga tata cara perbaikan lingkungan yang rusak. Jurnalisme lingkungan hidup dalam praktiknya memiliki beberapa tujuan antara lain (Sudibyo, 2014: 8): (a) Membantu masyarakat untuk mendapatkan kesadaran sosial atas apa yang sedang terjadi terhadap lingkungan mereka, (b) Membantu masyarakat mendapatkan informasi yang memadai untuk memutuskan sikap, (c) Menggerakkan masyarakat untuk terlibat dan bertindak dalam pelestarian lingkungan hidup. Persoalan lingkungan hidup, tidak terkecuali dengan sampah masker medis. Persoalan lingkungan yang muncul dari pandemi covid 19 ini tentunya perlu mendapat perhatian. Tidak hanya oleh pemerintah, melainkan juga bagaimana kesadaran masyarakat. Tentunya dari berbagai kalangan usia.

Generasi muda anak-anak sekolah dasar hingga tingkat menengah atas memerlukan edukasi tentang lingkungan hidup ini. Para siswa sekolah menjadi agen penting yang perlu diedukasi 
mengenai persoalan lingkungan hidup yang muncul akibat pandemi covid 19 tersebut. Untuk meningkatkan pengetahuan mengenai persoalan lingkungan hidup, tentunya dengan memberikan edukasi dan juga pelatihan menulis. Berdasarkan penelitian yang dilakukan oleh Abrar, storytelling adalah cara dalam penulisan persoalan lingkungan hidup yang akan lebih meyakinkan khalayak (Abrar, 2012).

Konsep ini berujung pada gaya narasi yang mempertimbangkan sifat tulisan, target tulisan, angle tulisan, dan bahasa. Cara meyakinkan khalayak ini adalah kemampuan yang dibutuhkan untuk bisa membantu masyarakat mendapatkan kesadaran sosial tentang persoalan sampah masker medis dan persoalan lingkungan lain akibat pandemi covid 19 ini. Edukasi lingkungan hidup bisa dimulai dalam proses belajar mengajar di tingkat sekolah. Terbukti beberapa sekolah sekarang menerapkan sistem sekolah alam, atau melakukan field trip sebagai metode untuk meningkatkan kepedulian siswa terhadap lingkungan hidup. Selain dapat meningkatkan kepedulian siswa terhadap lingkungan (alam), penerapan metode Field Trip juga dapat meningkatkan kepedulian siswa terhadap lingkungan sosial (Yulia \& Martuti, 2014). Olehnya, pelatihan ini dirasa perlu dan menjadi kebutuhan bagi para siswa khususnya SMAN 28 Jakarta Selatan. SMAN 28 merupakan sekolah berstatus unggulan di DKI Jakarta memiliki kelompok jurnalis yang perlu mendapat edukasi lebih mengenai praktik dari jurnalisme lingkungan hidup.

\section{METODOLOGI PELAKSANAAN}

Pelatihan ini dilakukan selama dua hari. Selama situasi Pandemi Covid-19 pihak mitra yaitu SMAN 28 Jakarta, masih membatasi pertemuan secara tatap muka. Sehingga, pelatihan ini juga dilakukan secara daring melalui Zoom meeting. Pelatihan melibatkan siswa dari jurusan IPA, IPS, dan Bahasa. Jumlah peserta terbanyak ialah siswa kelas X IPA. Peserta pelatihan berjumlah 80 orang. Adapun tahapan pelatihan ini adalah sebagai berikut: 


\section{Bagan 1. Pelaksanaan Kegiatan Pelatihan}

Memberikan soal pre test pada peseta pelatihan

Memberikan materi edukasi mengenai persoalan lingkungan hidup yang muncul di masa pandemi covi-29

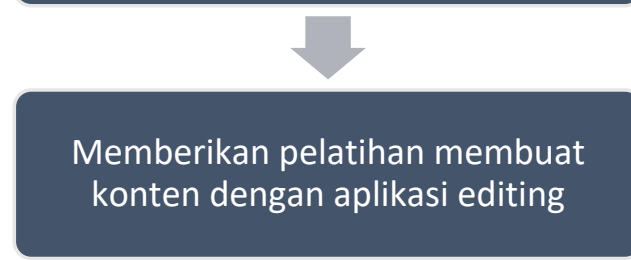

Peserta pelatihan membuat konten untuk media sosial terkait persoalan lingkungan hidup.

\section{Peserta pelatihan mengisi soal pos test yang diberikan oleh tim pengabdian}

Sumber: olahan pribadi

Pelatihan ini juga menggunakan metode ceramah, diskusi, dan juga praktik. Sehingga, para peserta pelatihan tidak hanya mendapatkan edukasi tentang pentingnya melakukan kampanye kepedulian terhadap lingkungan bersih, tetapi juga menjadi pelaku utama dalam mengedukasi followersnya. Pada hari pertama, pelatihan dilakukan dengan memberikan soal pre- test, memberikan materi tentang kearifan lokal lingkungan hidup di Indonesia, juga peran remaja untuk lingkungan hidup. Pada hari ke-dua, materi diisi dengan pelatihan menggunakan aplikasi editing untuk membuat konten lingkungan hidup yang tidak hanya edukatif tetapi juga menarik. Kemudian, para peserta membuat karyanya masing-masing yang juga diunggah pada akun media sosial Instagram. Sesi terakhir pelatihan, diisi dengan pemberian soal postest untuk mengetahui sejauh mana perbedaan sebelum dan sesudah mendapat pelatihan.

\section{HASIL DAN PEMBAHASAN}

Dari latar belakang permasalahan di atas, maka upaya utama yang dilakukan oleh tim pengabdian masyarakat adalah dengan memberikan edukasi mengenai persoalan lingkungan hidup yang terjadi di Indonesia, terutama selama masa pandemi covid-19. Persoalan sampah 
plastic hingga sampah medis menjadi soal utama. Tidak hanya itu, dalam pelatihan ini, tim juga memberikan penjelasan mengenai kearifan lokal lingkungan hidup di Indonesia. Seperti kearifan lokal Pikukuh oleh masyarakat Baduy, tradisi sasi pada masyarakat Maluku dan Papua. Menanam padi lokal pada masyarakat Cipta Gelar, Sukabumi. Juga kearifan lokal perladangan gilir balik masyarakat suku Dayak. Dari semua kearifan lokal tersebut, tim pengabdian memberikan penjelasan bahwa, di Indonesia sendiri, peran menjaga alam sudah menjadi kegiatan yang berlangsung lama sejak ratusan tahun lalu. Sehingga, upaya ini juga perlu dilakukan tidak terkecuali bagi kaum muda. Upaya-upaya penggerak seperti ini perlu dilakukan bahkan melalui edukasi di media sosial. Peran media sosial ini terbukti seperti yang dilakukan oleh pendakwah terkenal di Indonesia yaitu Aa Gym. Dalam penelitian yang dilakukan oleh Khotimah dan Mustika tahun 2021, Aa Gym melakukan komunikasi persuasif melalui akun instagramnya dalam mengedukasi para followersnya. Konten-konten tersebut sengaja dibuat untuk mengedukasi dan mempersuasif. Melalui Instagram, komunikasi persuasif akan semakin mudah dilakukan (Khotimah \& Mustika, 2021).

Penelitian ini menunjukkan bahwa, pemanfaatan Instagram sebagai media yang mengedukasi juga bisa dimanfaatkan untuk informasi dan kampanye lingkungan hidup. Dengan banyaknya informasi yang dibagikan melalui Instagram tentang masalah lingkungan hidup, maka gerakan kampanye kepedulian terhadap lingkungan hidup juga semakin mudah ditemui. Dalam pelatihan ini, tim memberikan edukasi bagaiman remaja saat ini mampu memanfaatkan Instagram sebagai media untuk membagikan topik-topik atau kajian tertentu mengenai persoalan lingkungan hidup. Sehingga, keterampilan mengolah informasi dan menyajikannya dalam Instagram juga dibutuhkan.

Setelah melakukan penyuluhan dengan ceramah dan diskusi, maka pelatihan dilanjutkan dengan penjelasan juga praktik membuat konten, menggali ide, dan editing melalui beberapa aplikasi. Kemampuan seperti ini dibutuhkan untuk membuat tampilan serta pesan lingkungan hidup tidak hanya informatif tetapi juga menarik. Bentuk pelatihan yang dilakukan adalah sebagai berikut:

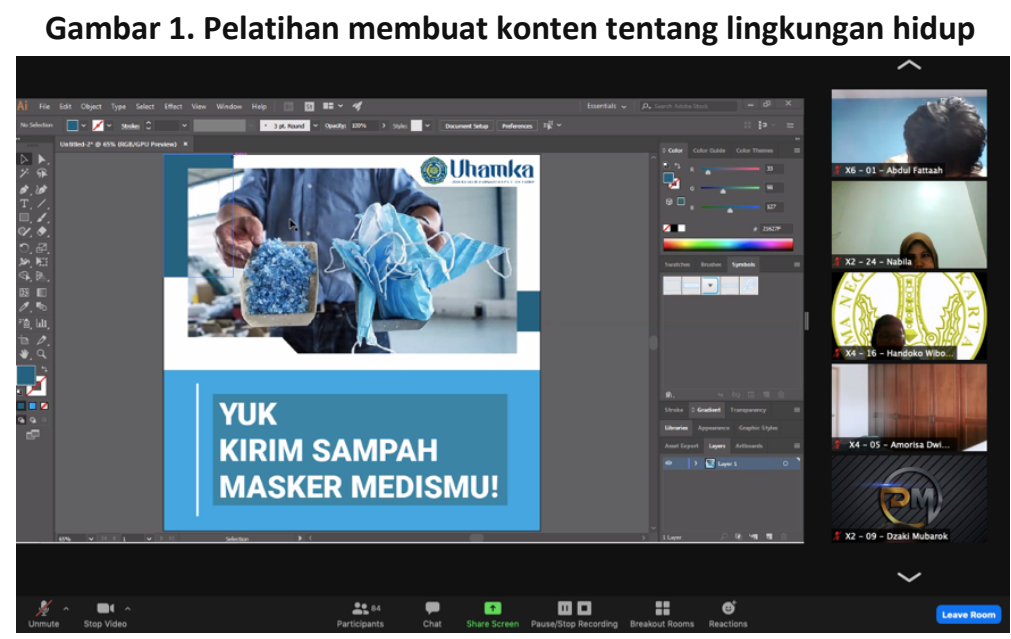




\section{Remaja dan Kampanye Lingkungan Hidup}

Kegiatan pengabdian ini melibatkan remaja SMA sebagai peserta utama atau mitra dalam pelatihan. Usia Remaja menjadi pengguna media sosial sebanyak 93,52\% di Insonesia (indonesiabaik.id). Olehnya, penggunaan media sosial ini menjadi salah satu cara yang bisa dilakukan oleh kaum remaja untuk melakukan edukasi, membagikan informasi, bahkan mengajak sesama pengguna muda lainnya untuk lebih peduli tentang persoalan lingkungan hidup. Pelatihan ini mecoba mengetahui pengetahuan para remaja peserta pelatihan, dengan memberikan beberapa soal pre-test dan pos test. Pertanyaan terkait ialah mengenai, ketertarikan para peserta terhadap informasi lingkungan hidup di Instagram, pengetahuan tentang peran remaja terhadap kampanye kepedulian lingkungan hidup, dan kemampuan membuat konten lingkungan hidup di media sosial Instagram mereka. Dari beberapa pertanyaan tersebut menunjukkan hasil sebagai berikut:

Tabel 1. Pemahaman Peserta Sebelum Pelatihan

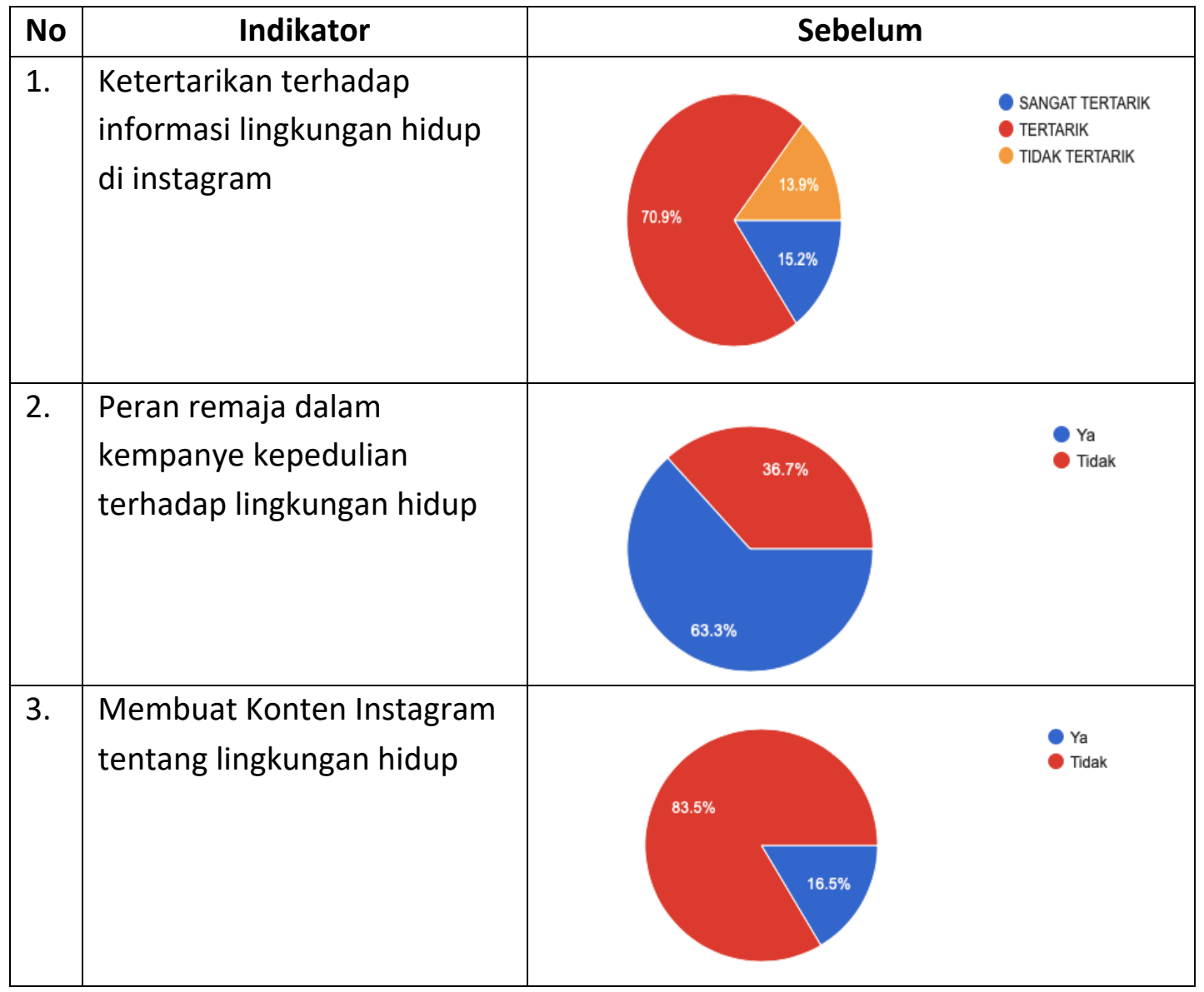

Para siswa SMAN 28 Jakarta memiliki ketertarikan terhadap informasi lingkungan hidup sebanyak 70,9\%. Namun, sebanyak 13,9\% menjawab tidak tertarik dengan persoalan lingkungan hidup. 63,3\% siswa menjawab peduli tentang persoalan lingkungan hidup. Dan sebanyak 83,5\% siswa SMAN 28 Jakarta tidak pernah membuat konten tentang lingkungan 
hidup. Setelah diberikan pelatihan, hasil pos test para peserta pelatihan adalah sebagai berikut:

Tabel 2. Pemahaman Peserta Sesudah Pelatihan

\begin{tabular}{|l|l|l|}
\hline No & \multicolumn{1}{|c|}{ Indikator } & \\
\hline 1. & $\begin{array}{l}\text { Ketertarikan terhadap } \\
\text { informasi lingkungan di } \\
\text { instagram }\end{array}$ & Sesudah Pelatihan \\
\hline 2. & $\begin{array}{l}\text { Peran remaja dalam } \\
\text { kempanye kepedulian } \\
\text { terhadap lingkungan hidup }\end{array}$ & \\
\hline 3. & $\begin{array}{l}\text { Membuat Konten } \\
\text { Instagram tentang } \\
\text { lingkungan hidup }\end{array}$ & Tiak \\
& & \\
\hline
\end{tabular}

Sebanyak $90,6 \%$ siswa tertarik dan merasa perlu mengakses informasi tentang lingkungan hidup. 90,6\% peserta pelatihan menjawab peduli terhadap persoalan lingkungan hidup, serta $65,6 \%$ mungkin akan membuat konten tentang kampanye lingkungan hidup, dan sebanyak $25 \%$ menjawab membuat konten lingkungan hidup.

Dari pelatihan ini, para siswa langsung diajarkan cara membuat konten yang edukatif dan juga menarik. Terutama mengampanyekan kepedulian terhadap penggunaan sampah plastik dan sampah medis khususnya masker sekali pakai. Persoalan ini yang perlu diangkat dan disebarkan secara lebih banyak lagi dalam media massa. Sehingga, karya-karya para siswa peserta pelatihan tersebut diutamakan memuat persoalan-persoalan lingkungan yang muncul selama masa pandemic covid-19 ini. beberapa karya yang dihasilkan oleh peserta pelatihan adalah sebagai berikut: 
Tabel 3. Karya Konten kampanye Peserta Pelatihan

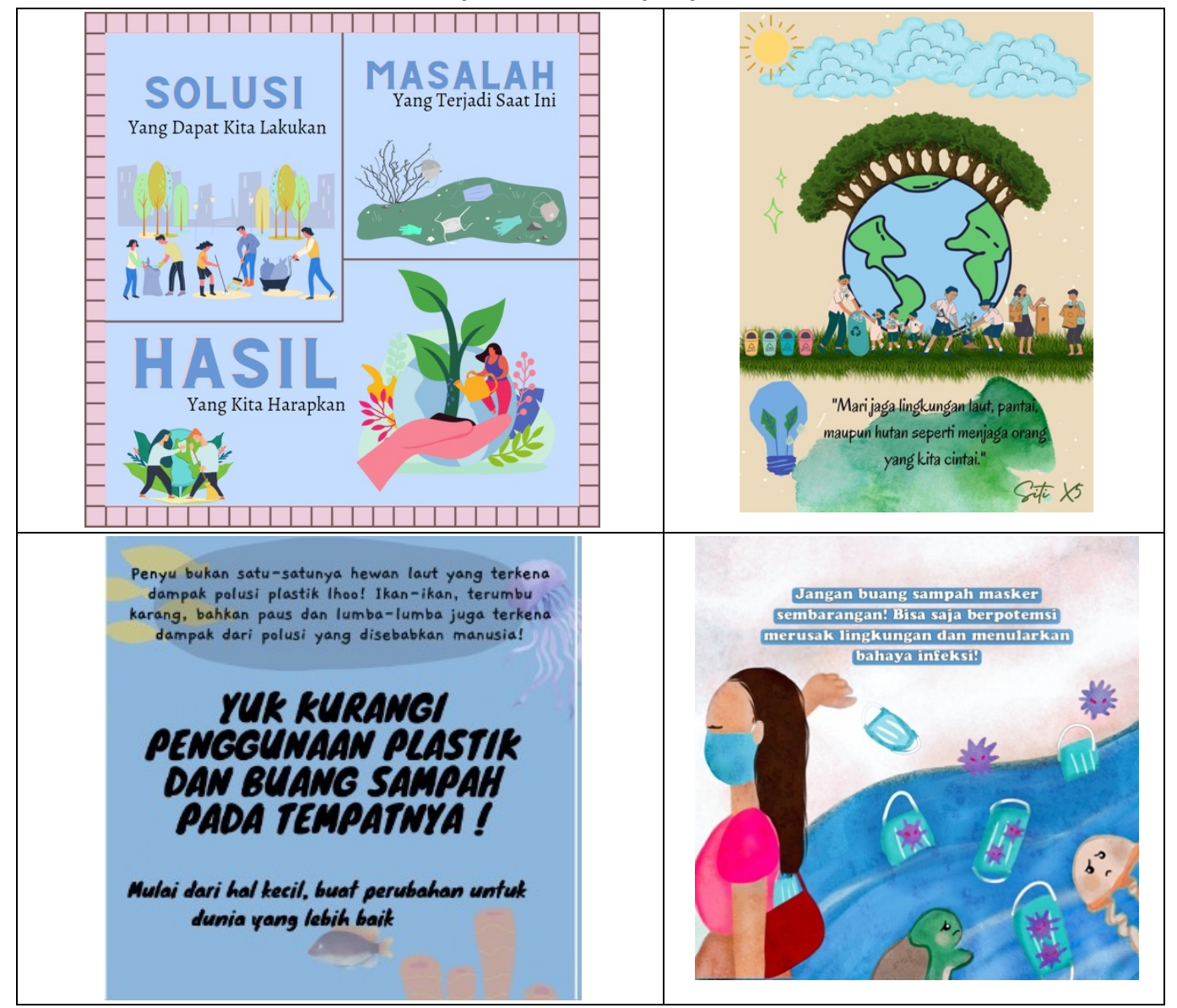

Karya para peserta pelatihan dibagikan pada akun Instagram, hal tersebut sebagai upaya menyosialisasikan tentang pentingnya menjaga lingkungan hidup bersih. Sebab, paling tidak dalam konten tentang lingkungan hidup yang dibuat, unsur advokasi yang memihak pada keberlangsungan lingkungan hidup juga menjadi tanggung jawab kita bersama.

\section{SIMPULAN}

Pada kegiatan pelatihan ini, tim pengabdian tidak menemukan kendala. Pelatihan berjalan sesuai dengan metode dan tahapan yang direncanakan. Hasil pelatihan ini juga dapat dilihat langsung dan diaplikasikan secara langsung oleh para peserta. Pelatihan tentang edukasi lingkungan hidup seperti ini masih jarang dilakukan, sehingga perlu adanya perluasan mitra yang membutuhkan edukasi seperti ini. tidak hanya itu, pelatihan serupa juga bisa dilakukan dengan membuat suatu karya yang membuat perubahan secara nyata, atau tidak hanya berhenti pada praktik edukasi dan persuasif. Kedepannya pelatihan tentang mengolah sampah plastic dan masker sekali pakai juga bisa dilakukan sebagai tindak lanjut dari kegiatan pengabdian ini. 


\section{DAFTAR PUSTAKA}

Abrar, A. N. (2018). Storytelling as a way of convincing audiences in environmental journalism. Jurnal Komunikasi Ikatan Sarjana Komunikasi Indonesia, 3(2), 84-90.

BBC.com, (2021). 100 Women: Salsabila Khairunisa, remaja Indonesia penggerak 'Mogok Sekolah untuk Hutan'. Diakses pada https://www.bbc.com/indonesia/majalah$\underline{55120379}$

Cox, Robert. 2010. Environmental Communication and the Public Sphere. New York: Sage Publication.

Khotimah, W. K. (2017). PROSES JURNALISME LINGKUNGAN HIDUP DI SURAT KABAR: STUDI DESKRIPTIF PADA REDAKSI RIAU POS TENTANG PEMBERITAAN KEBAKARAN HUTAN DAN LAHAN TAHUN 2017. In Prosiding Seminar Nasional Berseri (pp. 185-194).

Khotimah, W. Q., \& Mustika, S. (2021, November). Instagram and a Aa Gym's Persuasive Communication During the Covid-19 Pandemic. In 3rd Jogjakarta Communication Conference (JCC 2021) (pp. 219-223). Atlantis Press.

Oepen, Manfred and Hamacher, Winfried. 1999. Environmental Communication for Sustainable Development.

Saptoyo, R. D. A., (2021). Tiap Semenit Terdapat 2,8 Juta Limbah Masker Sekali Pakai di Bumi. Kompas.com. Diakses pada https://www.kompas.com/tren/read/2021/05/11/120500265/tiap-semenitterdapat-2-8-juta-limbah-masker-sekali-pakai-di-bumi?page=all, diakses 25/9/21, 05:17

Simanjuntak, M. H., (2021). Limbah medis COVID-19 dan pencemaran. AntaraNews. Diakses pada https://www.antaranews.com/berita/2315030/limbah-medis-covid-19dan-pencemaran, 25/9/21.

Sucipto, Cecep Deni. 2012, Teknologi Pengolahan Daur Ulang Sampah. Yogyakarta: Gosyen Publishing.

Violetta, P. T., (2021). Limbah medis dan penanganan darurat di era pandemi. AntaraNews.com. Diakses pada https://www.antaranews.com/berita/2315018/limbah-medis-danpenanganan-darurat-di-era-pandemi, 25/9/21.

Yuliati, T., \& Martuti, N. K. T. (2014). Efektivitas penerapan metode field trip untuk meningkatkan hasil belajar dan kepedulian siswa terhadap lingkungan. Jurna Pendidikan Matematika danSains, 2(2), 178-186. 